\title{
Genome-wide characterization of cellulases from the hemi-biotrophic plant pathogen, Bipolaris sorokiniana, reveals the presence of a highly stable GH7 endoglucanase
}

\author{
Shritama Aich ${ }^{2+}$, Ravi K. Singh ${ }^{1 \dagger}$, Pritha Kundu', Shree P. Pandey ${ }^{1 *}$ and Supratim Datta $2,3^{*}$
}

\begin{abstract}
Background: Bipolaris sorokiniana is a filamentous fungus that causes spot blotch disease in cereals like wheat and has severe economic consequences. However, information on the identities and role of the cell wall-degrading enzymes (CWDE) in B. sorokiniana is very limited. Several fungi produce CWDE like glycosyl hydrolases (GHs) that help in host cell invasion. To understand the role of these CWDE in B. sorokiniana, the first step is to identify and annotate all possible genes of the $\mathrm{GH}$ families like $\mathrm{GH} 3, \mathrm{GH} 6, \mathrm{GH} 7, \mathrm{GH} 45$ and $\mathrm{AA} 9$ and then characterize them biochemically.

Results: We confirmed and annotated the homologs of $\mathrm{GH} 3, \mathrm{GH} 6, \mathrm{GH} 7, \mathrm{GH} 45$ and AA9 enzymes in the B. sorokiniana genome using the sequence and domain features of these families. Quantitative real-time PCR analyses of these homologs revealed that the transcripts of the BsGH7-3 (3rd homolog of the GH 7 family in B. sorokiniana) were most abundant. BsGH7-3, the gene of BsGH7-3, was thus cloned into pPICZaC Pichia pastoris vector and expressed in X33 P. pastoris host to be characterized. BsGH7-3 enzyme showed a temperature optimum of $60^{\circ} \mathrm{C}$ and a pH $\mathrm{opt}_{\text {of }} 8.1$. BsGH7-3 was identified to be an endoglucanase based on its broad substrate specificity and structural comparisons with other such endoglucanases. BsGH7-3 has a very long half-life and retains 100\% activity even in the presence of $4 \mathrm{M} \mathrm{NaCl}, 4 \mathrm{M} \mathrm{KCl}$ and $20 \%(\mathrm{v} / \mathrm{v})$ ionic liquids. The enzyme activity is stimulated up to fivefold in the presence of $\mathrm{Mn}^{+2}$ and $\mathrm{Fe}^{+2}$ without any deleterious effects on enzyme thermostability.
\end{abstract}

Conclusions: Here we reanalysed the B. sorokiniana genome and selected one GH7 enzyme for further characterization. The present work demonstrates that BsGH7-3 is an endoglucanase with a long half-life and no loss in activity in the presence of denaturants like salt and ionic liquids, and lays the foundation towards exploring the Bipolaris genome for other cell wall-degrading enzymes.

Keywords: Bipolaris sorokiniana, Cell wall-degrading enzymes, Glycosyl hydrolase, GH7 endoglucanases, Salt tolerant, Alkaliphilic, Thermostable, Ionic liquids

\section{Background}

Biofuels produced from lignocellulosic biomass has many potential benefits over first-generation biofuel, including

\footnotetext{
*Correspondence: sppandey@iiserkol.ac.in; supratim@iiserkol.ac.in †'Shritama Aich and Ravi K. Singh contributed equally to this work ${ }^{1}$ Department of Biological Sciences, Indian Institute of Science Education and Research Kolkata, Mohanpur 741246, India

2 Protein Engineering Laboratory, Department of Biological Sciences, Indian Institute of Science Education and Research Kolkata, Mohanpur, India
}

Full list of author information is available at the end of the article lower $\mathrm{CO}_{2}$ emissions and no competition with food for human consumption. In lignocellulose, the cellulose and hemicellulose are embedded in a lignin matrix and not easily accessible to enzymes. Lignocellulolytic fungi can be an efficient source of specialized enzymes that aid in the degradation of complex plant cell wall components to produce sugars. The exact nature and relative abundances of these enzymes vary from one plant species to another or across tissues within a plant. One of the best known example is the cellulase cocktail, secreted by the 
soft rot fungus Trichoderma reesei in large quantities [1]. Recently, it was reported that $T$. reese $i$ being a necrophyte lacks several protein families related to infection and degradation of living plant tissue [2]. One way to get around this limitation is to add the missing enzymes in the cellulase cocktail or to manipulate the hydrolytic efficiency of cellulolytic enzymes encoded in this model organism. Another strategy could be to explore the fungal biodiversity for synergistic enzyme activities in order to supplement and increase the hydrolytic yield achieved by a $T$. reesei cocktail or, if possible, a new and more active cocktail based on enzymes from other organisms [3, 4].

Phytopathogenic fungi produce cell wall-degrading enzymes (CWDE) that are thought to aid their invasion into host cells [5]. A major group of CWDE consists of cellulases, which are glycosyl hydrolases (GHs) and catalyse hydrolysis of the $\beta-1,4$-glycosidic bonds in cellulose. Some of the CWDE-coding gene families have expanded during evolution among different groups of fungi $[6,7]$. Further, these enzymes also show preference for specific types of plant biomass $[8,9]$. Cellulases can be classified into three major types, namely endoglucanases (EG), cellobiohydrolases $(\mathrm{CBH})$ and $\beta$-glucosidases $(\mathrm{BG})$, all of which work synergistically to efficiently degrade cellulose [10-12].

Cochliobolus sativus (anamorph Bipolaris sorokiniana) is a fungal pathogen that causes spot blotch of wheat and barley and poses a severe challenge to their farming worldwide [13]. This fungal pathogen displays an enormous variability in its pathogenic, morphological and physiological forms. On the basis of their colony colour and growth behaviour, B. sorokiniana is broadly grouped into three categories. The black strain with thick dark mycelia are the most sporulating and aggressive kind, and the puffy white cotton-like mycelial strain is least sporulating but grows aggressively, while the mixed strain with greyish white mycelial growth has an intermediate number of spores and is the least aggressive [14, 15]. In addition, Bipolaris also attacks many grasses, including switch grass that is currently being developed as a bioenergy crop for biofuel production [16].

In 1999, Geimba et al. reported the partial purification and characterization of a BG from B. sorokiniana [17]. The same group in 2002 reported the presence of $\beta$-xylosidase, cellobiohydrolase and chitobiohydrolase activities in six isolates of $B$. sorokiniana originating from different areas of Brazil [18]. While a few loci have been stated to contain domains of the cellulolytic enzymes in B. sorokiniana genome (genome portal: Joint Genome Institute (JGI), University of California; http://genome. jgi-psf.org), systematic analysis of such genes across the genome or characterization of cellulase activities has not yet been reported [19]. A detailed characterization of these genes would be the first step towards the biotechnological application of these enzymes in biomass hydrolysis in addition or as an alternative to T. reesei cellulases and also for developing novel approaches towards biological control of pathogens. Here, we describe an integrative genomics approach to study the $B$. sorokiniana $\mathrm{GHs}$ and report the biochemical characterization of a novel GH7 endoglucanase.

\section{Methods \\ Identification and analysis of glycoside hydrolases (GH) homologs in B. sorokiniana}

The draft genome of $B$. sorokiniana lists 273 loci that are predicted to contain the domains of cellulases [19, 20]. In order to confirm and further annotate all possible genes of glycoside hydrolase family, we reanalysed the $B$. sorokiniana genome using the HMM (Hidden Markov model) profile-based search and phylogenybased clustering methods. We used protein sequences of the eukaryotic glycoside hydrolases, GH3, GH6, GH7, GH45 and GH61 [auxiliary activity family 9 (AA9)] from the CAZy database (http://www.cazy.org/), to construct the HMM profiles for each of the five GH family members [21]. The redundant sequences were removed from the dataset of each family using CDHIT [22]. Then, multiple sequence alignment (MSA) of each of the $\mathrm{GH}$ family members was performed using MAFFT $\mathrm{v} 7.123 \mathrm{~b}$ with default parameters [23]. These MSAs were used to construct the HMM profiles for each of the GH family members. Using these HMM profiles, the predicted proteome of $B$. sorokiniana was searched by HMMER program with the $E$ value set to $\leq 10^{-5}$. The predicted homologs were searched for the presence and distribution of domains using Pfam database [24]. The B. sorokiniana genes are prefixed as "Bs" followed by their family names. If a family contained more than one gene, they were sequentially numbered as per standard practice [25-28]. For example, GH7 family in B. sorokiniana contains six homologous genes, and therefore these are named as BsGH7-1 to BsGH7-6. Following a commonly accepted nomenclature, references to gene names and transcripts are italicized, whereas those to proteins are straight. Phylogenetic clustering of B. sorokiniana $\mathrm{GH}$ family members (GH3, GH6, GH7, GH45 and AA9) was performed by maximum likelihood (ML) method using RAxMLv7.2.8 [29]. We also used one bacterial protein from each family (GenBank IDs: AJP42775.1, AIF91560.1, AIQ82274.1 and AIF91527.1 for GH3, GH6, GH7 and GH45 families, respectively) as an out-group for phylogenetic analysis [30,31]. Clade robustness was assessed with 1000 bootstrap replications. FigTree was used to visualize the phylogenetic tree (http://beast.bio. ed.ac.uk/FigTree). The evolutionary divergence among 
GH family members was estimated using MEGA 6 [32]. The genomic architecture of homologs for each GH family member was generated using GSDS v2.0 server [33]. The coordinates of the intron-exon boundary were calculated using program 'blastn' on the genome sequence of B. sorokiniana (available at http://genome.jgi-psf. org/Cocsa1/Cocsa1.home.html) [19]. Percent identities between paralogs of each $\mathrm{GH}$ family were calculated with the help of Clustal Omega [34]. We used the HHpred server (http://toolkit.tuebingen.mpg.de/ hhpred/) to model the B. sorokiniana GH structure [35]. HHpred, at first, detects remote protein homology and then predicts structures from pairwise comparison of HMM profiles (through various databases, such as PDB, SCOP, Pfam, SMART, COGs and CDD) to produce query-template alignments. Further, it generates 3D structural models from these alignments. Root mean square deviations (RMSD; $\AA$ ) between structures were calculated using TMalign server (http://zhanglab.ccmb. med.umich.edu/TM-align/) [36]. Area and volume of the binding pocket on the structures were calculated using CASTp server (http://sts.bioe.uic.edu/castp/calculation. php) [37]. Distribution and arrangement of positive electrostatic patches on the structures were calculated using Patch Finder plus server (http://pfp.technion.ac.il/index. html) [38]. Pymol was used to visualize modelled structures and prepare figures [39].

\section{Culture maintenance and propagation}

Bipolaris sorokiniana was maintained under standard conditions recommended for culturing this fungus. Potato dextrose agar (PDA) has been used as a common medium for isolating Bipolaris from natural populations of wheat and barley and for maintaining and manipulating it in the laboratory [13-15, 40, 41]. The HD3069 strain with black morphology was maintained on PDA under complete darkness at $25{ }^{\circ} \mathrm{C}$ in a fungal incubator (Eyela, Model SU-1201) [13, 14]. The black strains are aggressive, produce maximum spores and are often used in characterization of plant responses to spot blotch attack [13-15]. Ten-day-old PDA plates were used for the collection of mycelial mass for isolation of nucleic acids.

\section{Transcriptional profiling by quantitative real-time PCR}

Approximately $200 \mathrm{mg}$ of crushed mycelial mass was used for RNA isolation. Total RNA of B. sorokiniana was extracted using the Trizol method following the manufacturer's instructions and treated with DNase enzyme (Invitrogen, Carlsbad, USA). cDNA was prepared using a Superscript III First-strand synthesis system, oligo-dT primers and $5 \mu \mathrm{g}$ of DNase-treated RNA following the manufacturer's protocol (Life Technologies, Carlsbad, USA).
Gene-specific primers for each GH family homolog (Additional file 1: Table S2a) were designed using Primer Express software version 3.0 (Applied Biosystems; http:// www.appliedbiosystems.com). SYBR green chemistry (KAPA Biosystems, Wilmington, USA) was used to estimate the transcript abundance of the $B$. sorokiniana $G H \mathrm{~s}$ using gene-specific primers. For determining the absolute amount of transcript, a standard curve was prepared for each of the genes using cDNA amounts corresponding to 50, 100, 150 and $200 \mathrm{ng}$ of total RNA in four replicates. Based on the formulae obtained from the standard curve, cDNA corresponding to 150 ng of total RNA was used to evaluate the absolute transcript amount based on their respective CT values. Three independent experiments were conducted, each comprising four replicates, the mean values were used to plot the graph. Elongation factor alpha $(\mathrm{EF}-\alpha)$ was used as an endogenous control.

\section{Statistical analysis}

The software Assistat 7.6 beta was used for statistical analysis to determine the significance of differences in the expression among the $G H$ members under study. Duncan multiple range test (DMRT) was performed at a level of $5 \%$ probability $(p \leq 0.05)$.

\section{Cloning of the BsGH7-3 gene}

All the chemicals used were of reagent grade. Medium for cell growth was purchased from HiMedia Laboratories (Mumbai, India). Restriction enzymes and polymerase enzyme used for PCR were from New England Biolabs (Beverly, USA) and Taq Polymerase from Biobharati LifeScience (Kolkata, India). Escherichia coli Top10F' cloning strain, Pichia pastoris yeast expression strain X33 and the vectors were from Life Technologies (Carlsbad, USA). The fraction obtained post purification was buffer-exchanged using a $30 \mathrm{kDa}$ cut-off size membrane of Amicon-Ultra-15 (Millipore, Darmstadt, Germany). Substrate and other reagents for enzymatic assays were purchased from Sigma-Aldrich (St Louis, USA).

BsGH7-3 was PCR amplified using the gene-specific primers (Additional file 1: Table S2b). The cDNA template was PCR amplified by Phusion ${ }^{\mathrm{TM}}$ high-fidelity DNA polymerase on a Veriti ${ }^{\circledR}$ thermal cycler (Life technologies, Carlsbad, USA) using $54-60{ }^{\circ} \mathrm{C}$ temperature gradient to identify the optimum conditions. PCR products were separated using 1\% agarose gel electrophoresis and specific DNA fragments were extracted using the QIAquick Gel extraction kit (Qiagen, Hilden, Germany). The gel-purified DNA was digested with XhoI and NotI$\mathrm{HF}$ and ligated to the linearized $\mathrm{pPICZ} \alpha \mathrm{C}$ vector. The ligated product was transformed into E. coli Top10F' and verified by colony PCR, unique site restriction digestion and DNA sequencing using $5^{\prime} \alpha$-factor and the $3^{\prime} \mathrm{AOX} 1$ 
(universal primer) of $\mathrm{pPICZ} \alpha \mathrm{C}$ as the sequencing primers.

\section{Expression and purification of the protein}

The plasmid construct was linearized using the unique site restriction enzyme, SacI within the $5^{\prime} \mathrm{AOX} 1$ region and integrated into the X33 P. pastoris host genome by transformation of the linearized construct into the X33 competent cells following the instructions provided with the Pichia EasyComp ${ }^{\mathrm{TM}}$ kit (Life technologies, Carlsbad, USA). Colony PCR (as per standard protocol) was used to screen for positively integrated Pichia clones and the Mut (methanol utilization) phenotype identified following the manufacturer's protocol (EasySelect ${ }^{\mathrm{TM}}$ Pichia expression kit, Life Technologies, Carlsbad, USA). Phenotype determination is required to verify if the $A O X 1$ gene is intact towards identifying the best medium for conducting the expression studies. To overexpress BsGH7-3, a $100 \mathrm{~mL}$ primary culture was grown in buffered complex glycerol (BMGY) medium with $100 \mu \mathrm{g} \mathrm{mL} \mathrm{m}^{-1}$ of zeocin. At O.D. 2.0 , the cells were harvested by centrifugation at $3000 \times g$ for $8 \mathrm{~min}$ and the pellet dissolved in buffered complex methanol (BMMY) medium such that the O.D. of the starter culture was 1.0. Cells were induced with $0.5 \%$ methanol every $24 \mathrm{~h}$ and grown for $96 \mathrm{~h}$. The protein secreted in the medium was precipitated with $50-80 \%$ ammonium sulphate and the cell pellet dialysed against $20 \mathrm{mM}$ phosphate buffer, $\mathrm{pH}$ 7.3. The protein was further purified by passing through a Macro-Prep Q column (Bio-Rad Laboratories, Hercules, USA) equilibrated with $20 \mathrm{mM}$ Tris- $\mathrm{HCl}$ buffer, $\mathrm{pH}$ 7.0, and eluted by $20 \mathrm{mM}$ Tris- $\mathrm{HCl} / 500 \mathrm{mM} \mathrm{NaCl}, \mathrm{pH}$ 7.0. After desalting the protein with $20 \mathrm{mM}$ phosphate buffer (pH 7.3), concentration was measured by Bradford assay with BSA and $\mathrm{A}_{280}$ and purity assessed by SDS-PAGE [42].

\section{Enzyme activity assays}

Activity of BsGH7-3 was measured by mixing $1 \mu \mathrm{g}$ of enzyme and $2 \%$ carboxymethyl cellulose (CMC; low viscosity of $100 \mathrm{cps}$ at $25{ }^{\circ} \mathrm{C}$ in $4 \%$ water and degree of polymerization 0.7) as a substrate in Mcllvaine buffer to a total reaction volume of $150 \mu \mathrm{L}$ and incubating the enzyme at $T_{\mathrm{opt}}$. DNS (3,5-dinitrosalicylic acid) assay was performed to measure the reducing ends of $\mathrm{CMC}$ after enzymatic reaction [43]. $150 \mu \mathrm{L}$ of DNS reagent (1.3 M DNS, $1 \mathrm{M}$ potassium sodium tartrate and $0.4 \mathrm{~N} \mathrm{NaOH}$ ) was added and the reaction mixture incubated at $95^{\circ} \mathrm{C}$ for $5 \mathrm{~min}$. Absorbance was measured at $540 \mathrm{~nm}$ after cooling the reaction mix to room temperature. One unit of endoglucanase activity is the amount of enzyme required to release $1 \mathrm{nmol}$ of reducing sugar per minute from the substrate. Glucose was used as the standard for the estimation of reducing sugars. All assays were performed in triplicate and standard deviation was calculated.

Determination of $\mathrm{pH}$ and temperature optima of $\mathrm{BsGH7-3}$ Using $\mathrm{CMC}$ as the substrate, the effect of temperature on enzyme activity was measured from 50 to $68{ }^{\circ} \mathrm{C}$ after incubating the enzyme in a buffer of optimum $\mathrm{pH}$ for 30 min. The optimal $\mathrm{pH}\left(\mathrm{pH}_{\mathrm{opt}}\right)$ was measured by quantitating the enzyme activity on $\mathrm{CMC}$ over a $\mathrm{pH}$ range of 5.2-8.6 using McIlvaine buffer ( $\mathrm{pH}$ 5.2-8.1) and Tris$\mathrm{HCl}$ buffer ( $\mathrm{pH} 8.0$ and 8.6 ). $\mathrm{pH}$ stability was measured by determining residual activity after incubating the enzyme in McIlvaine buffer $\mathrm{pH} 8.1$ for $6 \mathrm{~h}$ at $4{ }^{\circ} \mathrm{C}$.

\section{Effect of salt, metal ions, ionic liquids and detergents on BsGH7-3 activity}

The effects of additives were determined by measuring enzyme activity in the presence of salt, metal ions, ionic liquids and commercial detergents (Ariel ${ }^{\mathrm{TM}}$, Tide ${ }^{\mathrm{TM}}$, Sunlight $^{\mathrm{TM}}$ and SDS) in Mcllvaine buffer, $\mathrm{pH}$ 8.1. The additives were co-incubated with enzyme at $4{ }^{\circ} \mathrm{C}$ for $1 \mathrm{~h}$ before measuring the enzyme activity by standard activity assay. The specific activity without any additives was considered as $100 \%$ and relative activity in the presence of additives was estimated.

\section{Thermostability and half-life assay}

The thermostability of the enzyme was determined by incubating the enzyme in Mcllvaine buffer, $\mathrm{pH}$ 8.1, at $60{ }^{\circ} \mathrm{C}$. Residual enzyme activity was measured by removing aliquots at regular intervals to measure enzyme activity. The enzyme stability was also checked by assaying the enzyme after 30 days of incubation at $4{ }^{\circ} \mathrm{C}$ in $10 \mathrm{mM}$ phosphate buffer, $\mathrm{pH}$ 7.1.

\section{Substrate specificity and kinetic parameters of BsGH7-3 with $\mathrm{CMC}$ as a substrate}

The specificity of BsGH7-3 was determined by measuring specific activity across a range of substrates, namely lichenan (MP Biomedicals, Ohio, USA), $\beta$-D-glucan from barley, Avicel PH-101, CMC (Sigma-Aldrich, Saint Louis, USA) and phosphoric acid swollen cellulose (PASC). PASC was prepared following the protocol of Walseth et al. [44]. Activity was determined by incubating $1 \mu \mathrm{g}$ of enzyme with $0.8 \%$ substrate $(\mathrm{w} / \mathrm{v})$ at $60{ }^{\circ} \mathrm{C}$ for $30 \mathrm{~min}$ in Mcllvaine buffer $\mathrm{pH} 8.1$ and then measuring the reducing sugar generated by DNS assay. The specific activity on CMC was considered to be $100 \%$ and the relative activity on other substrates was estimated. The Michaelis-Menten parameters of GH7-3 on CMC was measured between 0.5 and $18 \mathrm{mg} \mathrm{mL}^{-1}$ of CMC and determined by a non-linear regression fit of Michaelis-Menten equation using GraphPad PRISM version 7.0 (GraphPad Software, La Jolla, CA). 
Effect of GH7-3 on the reduction of substrate viscosity $30 \%(\mathrm{w} / \mathrm{v})$ of substrate (lichenan and $\beta$-D-glucan) in McIlvaine buffer, $\mathrm{pH} 8.1$, was incubated with $36 \mu \mathrm{g}$ of GH7-3 for $60 \mathrm{~min}$ at $60{ }^{\circ} \mathrm{C}$ and cooled to room temperature. A capillary viscometer was used to measure the viscosity of the supernatant $(6 \mathrm{~mL})$ at room temperature with substrate viscosity in the absence of enzyme as the control. The viscosity reduction was calculated using the following equations [45]:

$$
\begin{aligned}
& \mu=\left(\mu_{\text {water }} \times t \times \rho\right) /\left(t_{\text {water }} \times \rho_{\text {water }}\right) \\
& \Delta \mu=\left(\mu_{\text {control }}-\mu\right) \times 100 /\left(\mu_{\text {control }}\right),
\end{aligned}
$$

where $\mu$ is the viscosity, $t$ is the total flow time through viscometer, $\Delta \mu$ is the reduction of viscosity and $\rho$ is the density.

\section{Results}

\section{Glycoside hydrolase $(\mathrm{GH})$ in B. sorokiniana: annotation} and sequence characterization

We performed a detailed genomic characterization of $\mathrm{GH}$ families in B. sorokiniana genome and targeted five putative cellulases across GH families (GH3, GH6, GH7, GH45 and AA9) in this analysis. These five families comprise the minimum set of cellulolytic enzymes (EGs, CBHs and BGs) that are required for biomass hydrolysis and its identification is a step towards the search for all such cell wall-degrading enzymes in B. sorokiniana [46]. Using the HMM profile search and phylogenetic clustering methods, we confirmed the identity of $15,3,6,3$ and 23 B. sorokiniana homologs of GH3, GH6, GH7, GH45 and AA9, respectively, as initially determined by $\mathrm{Ohm}$ et al. [19] (Fig. 1; Additional file 1: Figures S1, S2, Table S1). One additional homolog of the AA9 family was identified in this study (locus ID: jgi|Cocsa1|155289|gm1.10_g) (Fig. 1; Additional file 1: Figures S1, S2, Table S1). The homologs of each $\mathrm{GH}$ family varied in the lengths of the gene as well as their transcripts (Additional file 1: Figures S1, S2, Table S1). The members of AA9 are of relatively shorter length, while the GH3 members were larger (Additional file 1: Figures S1, S2, Table S1). Further, we found variable number of introns among the homologous genes in each $\mathrm{GH}$ family (Additional file 1: Figure $\mathrm{S} 2$, Table S1). Interestingly, some members of GH3, GH6 and AA9 families are intron less (Additional file 1: Figure $\mathrm{S} 2$ ). The sequences of the homologs of each $\mathrm{GH}$ family in $B$. sorokiniana have diverged differently (Additional file 1: Figure S3). For example, the members of GH3 family are more diverged with mean identity $29 \%$, while GH7 family members are relatively less diverged with $52 \%$ identity. Homologs in each family have the characteristic domain of their respective family (Fig. 1a). GH6, GH7, GH45 and AA9 family members are single domain proteins, while most of the GH3 family members contain two domains (GH3 N-terminal and GH3 C-terminal) with the exception of GH3-14 and GH3-15, which only contains a GH3 N-terminal domain (Fig. 1a) (Additional file 1: Figure S1). Additionally, GH3 family members also have a 'Fn3-like' domain at the C-terminal [except in GH3-13 and GH315] (Fig. 1a). GH3-5 contains two additional domains at the C-terminus, 'CPSase_sm_chain' and 'GATase.' GH3-13 contains a 'P450' domain at the N-terminal end and GH314 contains a 'GNAT' domain at the C-terminus. Interestingly, only five of the members in AA9 family contain an additional cellulose binding module (CBM1 domain) at the C-terminus (Fig. 1a; Additional file 1: Figure S1).

We used maximum likelihood (ML) methods to determine the phylogenetic clustering among the GH family members in B. sorokiniana and obtained five robust clusters each for GH3, GH6, GH7, GH45 and AA9 (Fig. 1b). The GHs from bacteria are clustered within the clade of the respective families to indicate that horizontal gene transfer events might have played an important role in the evolution of GHs in B. sorokiniana and other fungi [47]. Variation in branch lengths suggests that after divergence from their common ancestor, the five $\mathrm{GH}$ families evolved at varied rates before their further duplication and expansion, resulting in high sequence diversities (Fig. 1b, c). We found maximum evolutionary divergence between GH6 and GH7 families with 9.155 amino acid substitutions per site (Fig. 1c). The large number of poorly aligned regions is also evident from the MSA (Additional file 1: Figure S3).

\section{Transcriptional profiling of glycoside hydrolases in $B$. sorokiniana}

We set out to identify the minimum set of enzymes across endoglucanases, cellobiohydrolases and $\beta$-glucosidases in $B$. sorokiniana and succeeded in annotating all of these five $\mathrm{GH}$ families. Of these, endoglucanases and cellobiohydrolases are found across GH6, GH7 and GH45 and catalyse the hydrolysis of the $\beta(1,4)$ cellulose bond to produce cellobiose. The GH3 further catalyses the hydrolysis of cellobiose into glucose. GH61 is the AA9 copper-dependent oxidative enzyme family [20]. Considering the role in driving committed reactions in cellulose degradation, we started by studying the following three families: GH6, GH7 and GH45.

We investigated the abundances of the mRNAs of three homologs of $B s G H 6$, six belonging to $B s G H 7$ and two of $B s G H 45$, in the constitutive states. Among the three gene families, GH7 showed higher level of transcript accumulation in three of its homologs, GH7-3, GH7-4 and GH7-6, followed by GH7-1, GH7-2 and GH7-5. After GH7, GH6-1 showed significantly higher accumulation compared to its other two homologs. GH45-2 showed 


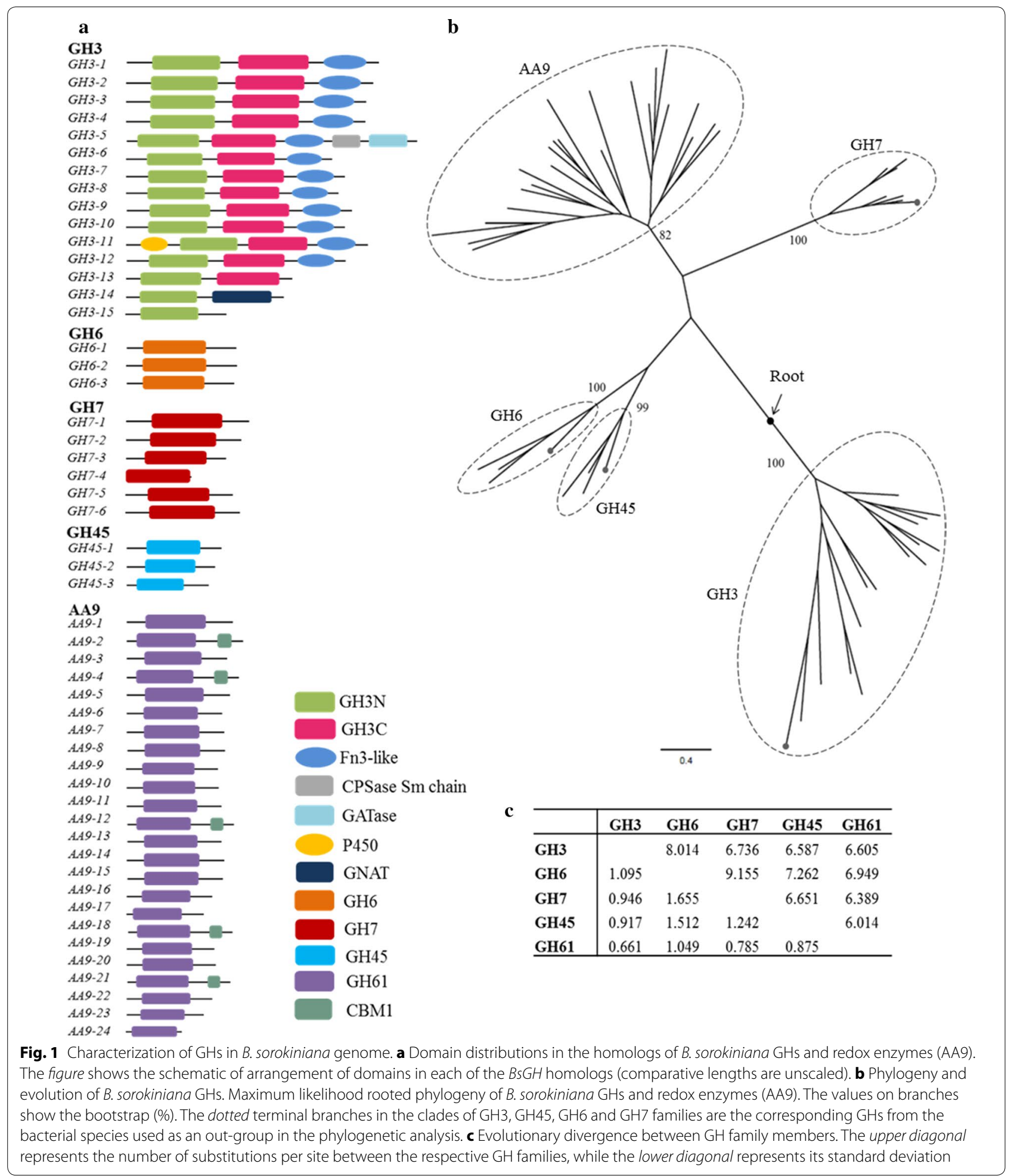

comparatively less accumulation compared to GH45-1 (Fig. 2). Maximum transcript abundance was recorded for GH7-3 and therefore the gene was chosen for biochemical characterization.
Biochemical characterization of BsGH7-3

The open reading frame encoding BsGH7-3 was cloned into a Pichia pPICZ $\alpha \mathrm{C}$ expression vector and verified by sequencing. The sequenced product showed a $100 \%$ 


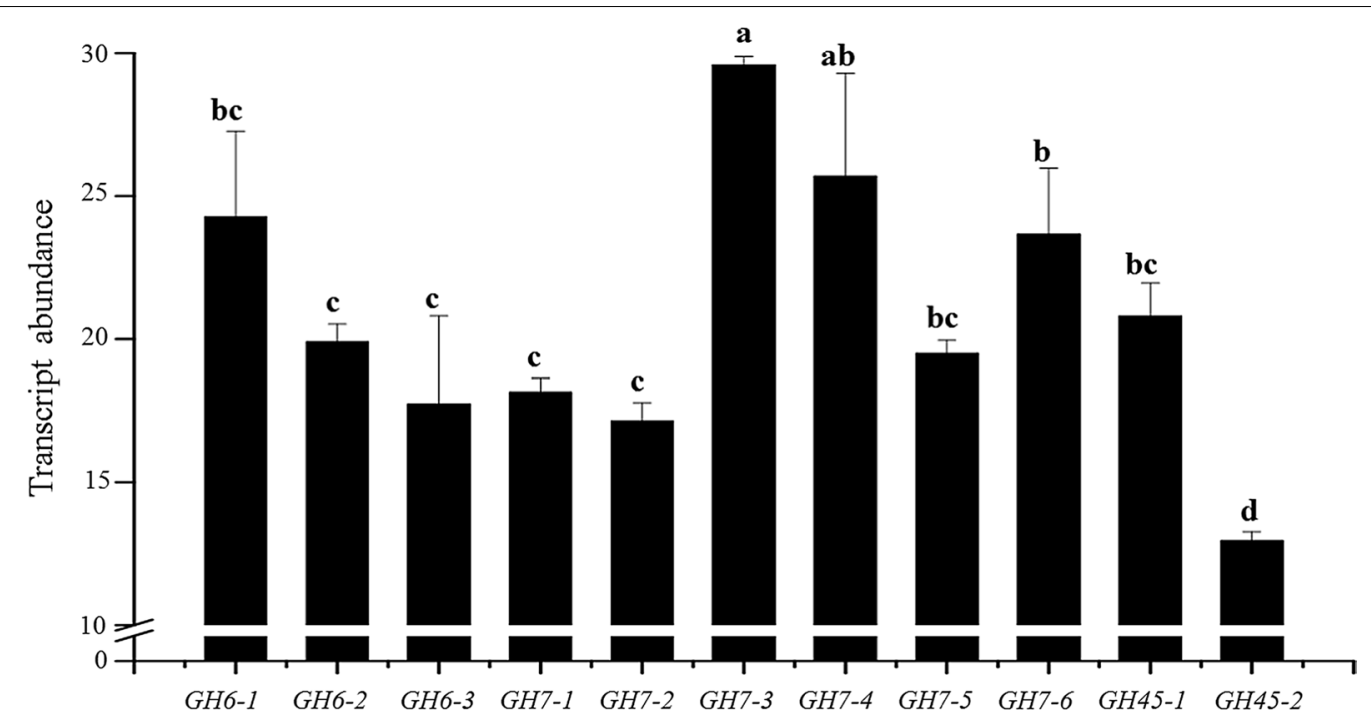

Fig. 2 Transcript abundance of the GH family genes in B. sorokiniana. A standard curve using known amounts of cDNA was prepared for the three homologs of $B s G H 6$, six belonging to $B s G H 7$ and two of BsGH45; (further details in "Results") in four replicates. Based on the standard curve, $C D N A$ corresponding to $150 \mathrm{ng}$ of total RNA was used to evaluate the absolute transcript amount based on the respective CT values. Three independent experiments were conducted, each comprising four replicates, and the mean values were used to plot the graph. Data are represented as mean \pm SE. Assistat 7.6 beta was used for statistical analysis (DMRT-Duncan multiple range test). The Duncan test at a level of $5 \%$ of probability was applied. Bars with the same letter do not differ statistically between themselves $(p \leq 0.05)$

sequence match to the nucleotide sequence of the predicted GH7-3 in the Bipolaris genome (Additional file 1: Figure S4). Protein obtained after ammonium sulphate precipitation and anion exchange chromatography was analysed by SDS-PAGE, and the molecular weight of BsGH7-3 was in agreement with the apparent molecular mass of $46.6 \mathrm{kDa}$ calculated from the sequence (Fig. 3a). The enzyme preparation had a specific activity of $5967 \mathrm{U} \mathrm{mg}^{-1}$ ( $1 \mathrm{U}=1 \mathrm{nmol}$ of reducing sugars formed per min per mg of BsGH7-3; Fig. 3b).

BsGH7-3 maintained a broad activity range over $\mathrm{pH}$ 5.0-9.0 though the $\mathrm{pH}$ optimum $\left(\mathrm{pH}_{\text {opt }}\right)$ is 8.1. The enzyme retains $66 \%$ of its activity at $\mathrm{pH} 5.4$ and $70 \%$ activity at $\mathrm{pH} 8.6$ after overnight incubation at $4{ }^{\circ} \mathrm{C}$ (Fig. 3). Temperature optimization studies at $\mathrm{pH} 8.1$ showed that at $60^{\circ} \mathrm{C}$ the purified BsGH7-3 had the maximum cellulase activity (Fig. 3c).

BsGH7-3 activity was found to be stimulated by $\mathrm{Mn}^{+2}$ and $\mathrm{Fe}^{+2}$ in Mcllvaine buffer, $\mathrm{pH} 8.1$ (Table 1). Both metal ions together also stimulate the enzyme, resulting in a $512 \%$ increase in relative specific activity on CMC. Upon incubation of the enzyme in the presence of $\mathrm{Mn}^{+2}$ and $\mathrm{Fe}^{+2}$ for $72 \mathrm{~h}$ at $T_{\text {opt }}$ in McIlvaine buffer $\mathrm{pH}$ 8.1, only $13 \%$ decrease in relative activity is observed. The metal ions could be easily removed by passage through a column packed with Chelex ${ }^{\circledR} 100$ resin (Sigma-Aldrich, St. Louis, USA), indicating the absence of specific metal binding site(s). In addition, inductively coupled plasma mass spectrometry (ICP-MS) measurements also confirmed the removal of all manganese and ferrous ions (data not shown). When enzyme activity was again measured with the metal-stripped enzyme on CMC, the specific activity decreased to the level prior to metal addition. Endoglucanases are not known to require metals as a cofactor, though there are previous reports of such proteins being stimulated by metal ions $[48,49]$. In the presence of $4 \mathrm{M} \mathrm{KCl}$ and $4 \mathrm{M} \mathrm{NaCl}$, the specific activity of BsGH7-3 increased by 25 and $10 \%$, respectively (Table 1). Thus, BsGH7-3 is salt tolerant. To determine the enzyme's robustness and potential use in industrial applications, BsGH7-3 activity was measured in the presence of a few readily available commercial detergents. The enzyme showed maximum stability in the presence of Tide $^{\mathrm{TM}}$ (Procter \& Gamble, Mumbai, India), with a residual activity of $69 \%$ after incubation for $1 \mathrm{~h}$ at $60{ }^{\circ} \mathrm{C}$ (Table 1). In the presence of Ariel ${ }^{\mathrm{TM}}$ (Procter \& Gamble, Mumbai, India), SDS (Sigma-Aldrich, St. Louis, USA) and Sunlight ${ }^{\mathrm{TM}}$ (Hindustan Unilever, Mumbai, India), the enzyme residual activity was 62,51 and $74 \%$, respectively (Table 1). Thus, BsGH7-3 is stable in the presence of detergents.

After incubation at $60{ }^{\circ} \mathrm{C}$ for $365 \mathrm{~h}$ (15.2 days), BsGH7-3 retained $66 \%$ of its specific activity (Fig. 3b). Further, upon incubating the enzyme for 30 days at $4{ }^{\circ} \mathrm{C}$, a residual specific activity of $93 \%$ was retained. Ionic liquids (ILs) hold great promise for biomass pretreatment 


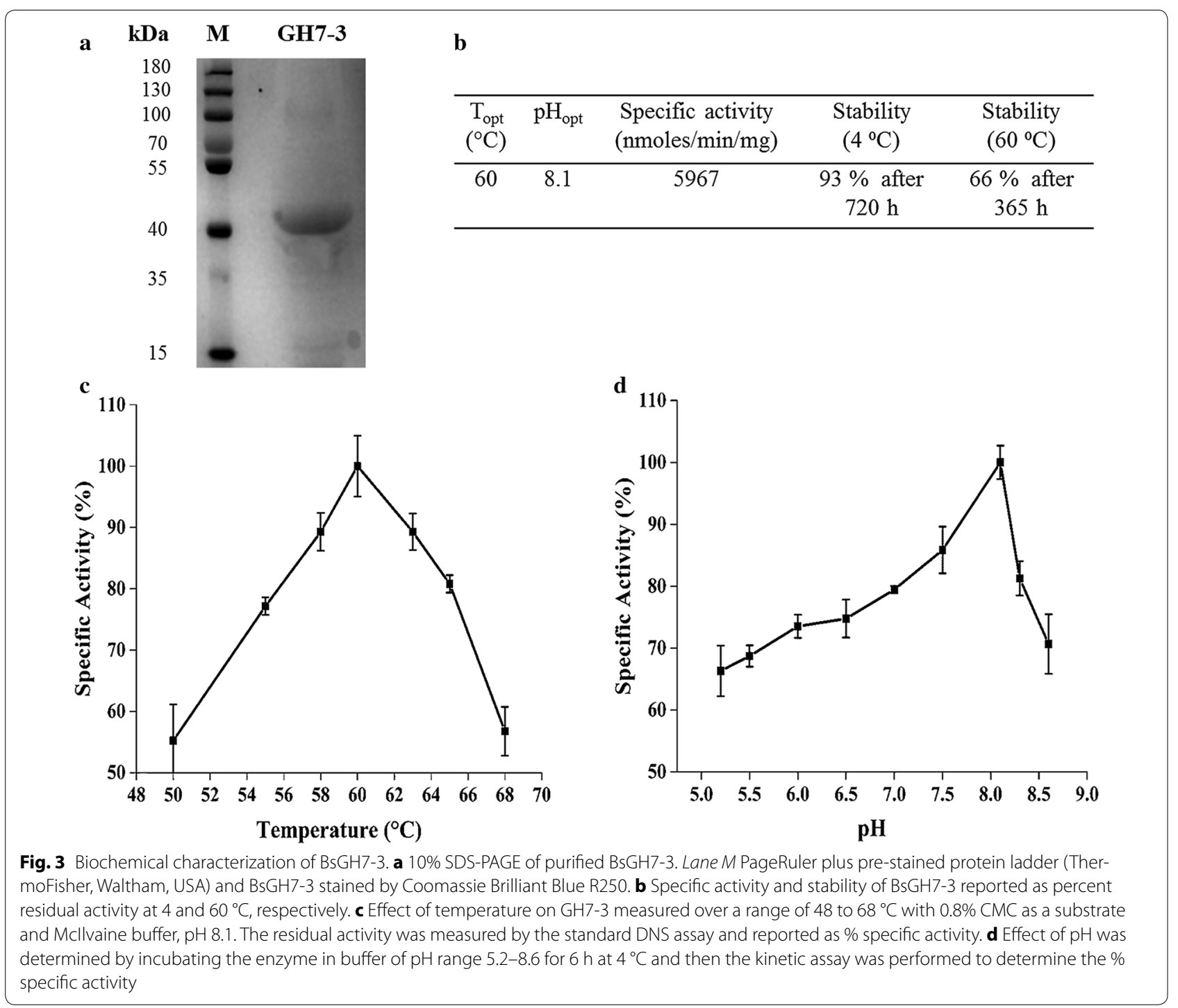

and thus have been the subject of many studies towards understanding its compatibility with enzymes. Since ILs have been generally known to denature cellulase, we desired to test BsGH7-3 stability against three ILs as a further probe of enzyme thermostability [50-52]. In the presence of $20 \%(\mathrm{v} / \mathrm{v})$ 1-ethyl-3-methyl imidazolium chloride $\left(\left[\mathrm{C}_{2} \mathrm{C}_{1} \mathrm{im}\right][\mathrm{Cl}]\right)$, 1-ethyl-3-methyl imidazolium phosphate $\left(\left[\mathrm{C}_{2} \mathrm{C}_{1} \mathrm{im}\right]\left[\mathrm{C}_{2} \mathrm{C}_{2} \mathrm{PO}_{4}\right]\right)$ and 1-ethyl-3-methyl imidazolium acetate $\left(\left[\mathrm{C}_{2} \mathrm{C}_{1} \mathrm{im}\right]\left[\mathrm{MeCO}_{2}\right]\right)$, the enzyme activity is unaffected (Table 1). BsGH7-3 is thus a very stable enzyme with a very long half-life.

BsGH7-3 showed the highest activity towards lichenan, with the relative activity being $367 \%$ as compared to $\mathrm{CMC}$. The relative specific activity towards $\beta$-D-glucan is $174 \%$ and decreases to 68 and $57 \%$ towards PASC and Avicel, respectively (Table 2). The steady-state kinetic parameters of BsGH7-3 were measured under optimal assay conditions $\left(30 \mathrm{~min}, \mathrm{pH} 8.1,60^{\circ} \mathrm{C}\right.$ ) by varying the $\mathrm{CMC}$ concentration and the data fit using a non-linear regression method (Fig. 4). The enzyme had the $K_{\mathrm{m}}, V_{\max }$ and $k_{\text {cat }}$ values of $0.75 \mathrm{mg} \mathrm{mL}^{-1}, 21.64 \mu \mathrm{M} \mathrm{min}{ }^{-1}$ and $288 \mathrm{~min}^{-1}$, respectively. BsGH7-3 also decreases the viscosity of lichenan by $11.42 \%$ and of $\beta$-D-glucan by $9.8 \%$, indicating that BsGH7-3 had a positive effect on viscosity reduction of substrates.

\section{Structural insights into the GH7-3 function}

While the GH7 enzyme family contains both $\mathrm{CBH}$ (Cel7A) and EG (Cel7B) enzymes with a similar $\beta$-sheet sandwich motif, differences exist. For example, endoglucanases have substrate tunnel-associated peptide loops of shorter lengths compared to cellobiohydrolases. To get an insight into the function of BsGH7-3, we modelled the structure of BsGH7-3. A HMM-based homology 
Table 1 Effect of metal ions, salts, ionic liquids and detergents on the specific activity of BsGH7-3 and measured by standard spectrophotometric assay

\begin{tabular}{|c|c|}
\hline Reagents & Specific activity (\%) \\
\hline \multicolumn{2}{|l|}{$10 \mathrm{mM}$ metal ions } \\
\hline Magnesium chloride & $91 \pm 7$ \\
\hline Copper sulphate & $100 \pm 1$ \\
\hline Manganese chloride & $444 \pm 3$ \\
\hline Ferrous sulphate & $304 \pm 2$ \\
\hline Manganese chloride + ferrous sulphate & $512 \pm 5$ \\
\hline Ferric chloride & $179 \pm 1$ \\
\hline Calcium chloride & $113 \pm 5$ \\
\hline Nickel sulphate & $114 \pm 4$ \\
\hline Zinc acetate & $97 \pm 2$ \\
\hline \multicolumn{2}{|l|}{4000 mM salt } \\
\hline Potassium chloride & $124 \pm 3$ \\
\hline Sodium chloride & $109 \pm 2$ \\
\hline \multicolumn{2}{|l|}{$20 \%$ ionic liquid } \\
\hline$\left[\mathrm{C}_{2} \mathrm{C}_{1} \mathrm{im}\right]\left[\mathrm{C}_{2} \mathrm{C}_{2} \mathrm{PO}_{4}\right]$ & $112 \pm 3$ \\
\hline$\left[\mathrm{C}_{2} \mathrm{C}_{1} \mathrm{im}\right]\left[\mathrm{MeCO}_{2}\right]$ & $122 \pm 2$ \\
\hline$\left[\mathrm{C}_{2} \mathrm{C}_{1} \mathrm{im}\right][\mathrm{Cl}]$ & $107 \pm 3$ \\
\hline \multicolumn{2}{|l|}{$7 \mathrm{mg} \mathrm{mL}^{-1}$ detergents } \\
\hline Ariel $^{\mathrm{TM}}$ & $62 \pm 5$ \\
\hline Tide $^{\mathrm{TM}}$ & $69 \pm 4$ \\
\hline Sunlight ${ }^{\mathrm{TM}}$ & $74 \pm 4$ \\
\hline SDS & $51 \pm 3$ \\
\hline
\end{tabular}

$100 \%$ specific activity $=$ GH7-3 CMC activity in the absence of any additives

Table 2 Relative substrate specificity of recombinant BsGH7-3

\begin{tabular}{lll}
\hline $\mathbf{0 . 5} \%$ substrate & Main linkage & Specific activity (\%) \\
\hline Lichenan & $1,3-1,4-\beta$-(glucose) & $367 \pm 31$ \\
$\beta$-D-Glucan & $1,3-1,4-\beta$-(glucose) & $175 \pm 15$ \\
CMC-Na & $1,4-\beta$-(glucose) & 100 \\
PASC & $1,4-\beta$-(glucose) & $69 \pm 4$ \\
Avicel & $1,4-\beta$-(glucose) & $57 \pm 9$ \\
\hline
\end{tabular}

Specific activity with CMC as a substrate and in the absence of any additives is considered as $100 \%$

search predicted Humicola insolens GH7 (HiGH7, PDB ID: 1OJJ) as the best template for BsGH7-3. These two sequences are 53\% identical (Fig. 5a; Additional file 1: Figure S5a). T. reesei GH7 (PDB ID: 7CEL; TrGH7), which is the most studied cellobiohydrolase $(\mathrm{CBH})$, on the other hand possess a sequence identity of $38 \%$ with BsGH7-3 (Fig. 5a; Additional file 1: Figure S5a). Residues in the A loop (A1, A2 and A3) and B loop (B1 and B4) of BsGH7-3 are more identical to HiGH7 than TrGH7 (Fig. 5a). TrGH7 contains three additional but functionally important loops characteristic of $\mathrm{CBHs}$ (tunnel

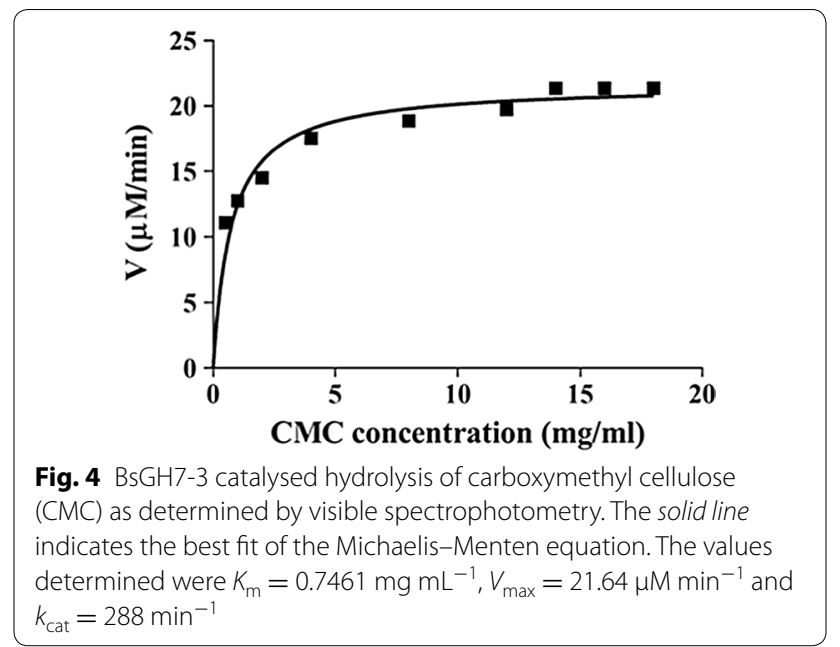

exit motif A4, and B2 and B3) that are absent in endoglucanases, including in BsGH7-3 and HiGH7. TrGH7 exhibits variations in all motifs, except $\mathrm{T} 3$ containing the catalytic residues (Fig. 5a). Although several GH7 enzymes ( 6 out of 27 endoglucanases and 27 out of 57 cellobiohydrolases) contain a carbohydrate binding module (CBM), BsGH7-3 does not contain any known CBM domain. Two characteristic Arg residues of $\mathrm{CBH}$, Arg251 and Arg 394 in TrCel7A, are absent in BsGH7-3. Arg251 located at the base of loop B3 in TrCel7A has been implicated in coordination of the reaction product cellobiose but is absent in endoglucanases [53]. Similarly, Arg394 in TrCel7A is a key factor in processive motion of CBHs and is absent in the non-processive endoglucanases [54].

While the overall modelled structure of BsGH7-3 is not significantly different from TrGH7 (RMSD < 3Å; Fig. 5b; Additional file 1: Figure S5a), variations in the size and shape of the substrate binding tunnel were evident. The tunnel in BsGH7-3 appears to resemble a shallow crevice with inner solvent-accessible surface area of $3793.1 \AA^{2}$ compared to the $3879.3 \AA^{2}$ deep tunnel in TrGH7 (Fig. 5b). BsGH7-3 also shows striking differences in the area and volume of the largest binding pocket and the number of residues in the largest electrostatic patch on the protein surface compared to $\mathrm{HiGH} 7$ and $\mathrm{TrGH} 7$ (Additional file 1: Figure S5b). BsGH7-3 has a smaller binding pocket and the largest electrostatic patch is made up of only five residues (Additional file 1: Figure S5b). Further, the electrostatic potential distribution and its pattern on the surface vary between BsGH7-3, HiGH7 and TrGH7 (Additional file 1: Figure S5c). TrGH7 has relatively more negative patches than HiGH7 and BsGH7-3. Such differences in the electrostatic charge distribution may influence the interaction of protein with salt and ionic liquids. 
a

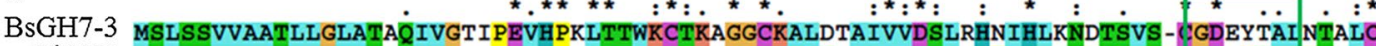
HiGH7 7 . TrGH7 -

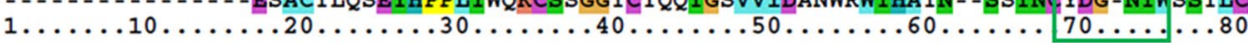
B1

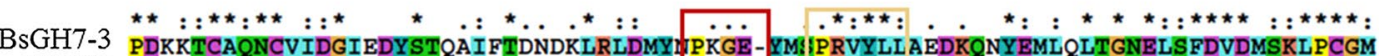
HiGH7 PDVESCAKNCIMEGIPDYSOYGVTTNGTSLRLQHI-PDGR-VP IPRVYLIDKTKRRYEMLHLTGFEFTFDVDATKLPCGM TrGH7 PDNETCAKNCCLDGAAYASTYGVTTSGNSLSIDFVFQSAQKNV(IARLYLMASDT-TYQEFTLLGNEFSFDVDVSQLPCGL

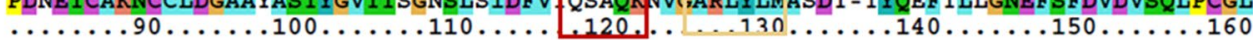
Catalytic motif A1 $T 1$

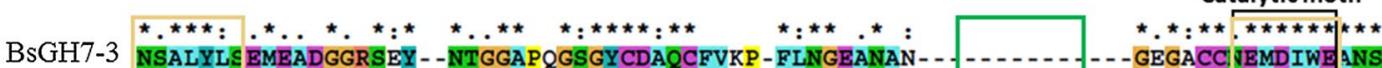
HiGH7 NSALYL BMHPTGAKSKY - -NPGGAYYGTGYCDAQCFVTP-FINGLGNIB-TrGH7 NGALYFV SMDADGGVSKYPTNTAGAKYGTGYCDSQCPRDLKFINGQANVEGWE PSSNNAN] GIGGHGSCC EMMDIWE ANS

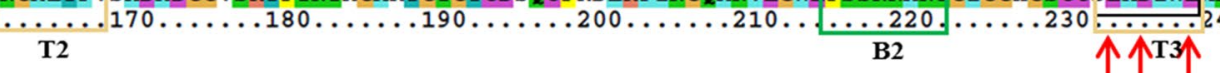

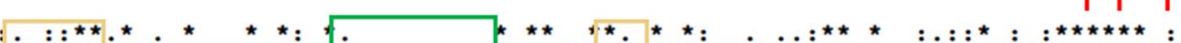

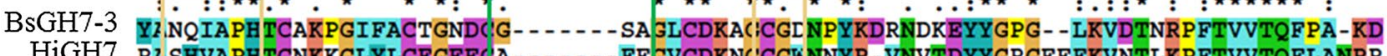
HiGH7 R] SHVAPHTCNKKGLYLCEGEEC ('A- - - - - - FE GVCDKNC:CGK NNYR-VNVTDYYGRGEEFKVNTLKPFTVVTQFLANRR

TrGH7 IS:EALTPHPCTTVGQEICEGDGC:GGTYSDNRYG GTCDPDC:CDKNPYR-LGNTSFYGPGSSFTLDTTKKLTVVTQFET- - $\ldots \ldots 250 \ldots \ldots 260 \ldots \ldots 270 \ldots \ldots 28 \ldots \ldots \ldots 290 \ldots \ldots 310 \ldots \ldots \ldots 320$ T4 B3 T5

$$
\star \star \star \star \star * \star \text {. : : : : }:::::^{*}:
$$

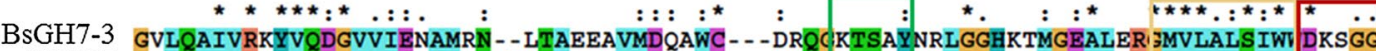
HiGH7 GKLBKIHRFYVQDGKVIBSFYTNKEGVPYTNMIDDEFC---EATC - SRKYMELGATQGMGEALTR IMVLAMSIWV DQGGN TrGH7 --SGAINRYYVQNGVTFQQPNAEL-GSYSGNELNDDYCTAEEAEHGGSSF SDKGGLTQFKKATSG JMVLVMSLWI DYYAN $\ldots \ldots 330 \ldots \ldots 340 \ldots \ldots 350 \ldots \ldots 360 \ldots \ldots 370 \ldots \ldots 380 \ldots \ldots 390 \ldots 20$ B4

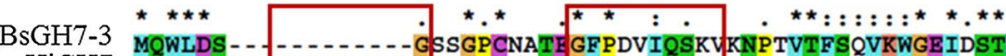
MEWLDH - - - - - - GEAGPCAKGE GAPSNIVQVEPFPEVTYTNLRWGEIGSTYQELQ - - - - . TrGH7 MLWLDSTY TNETSSTPGAVRGSCSTSSGVPAQVESQSPNAKVTFSNIKFGPIGSTGNPSG - . . . . .

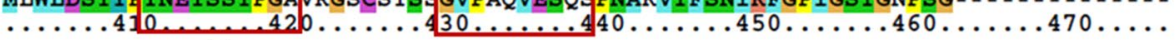
A4 A2

b TrGH7 HiGH7
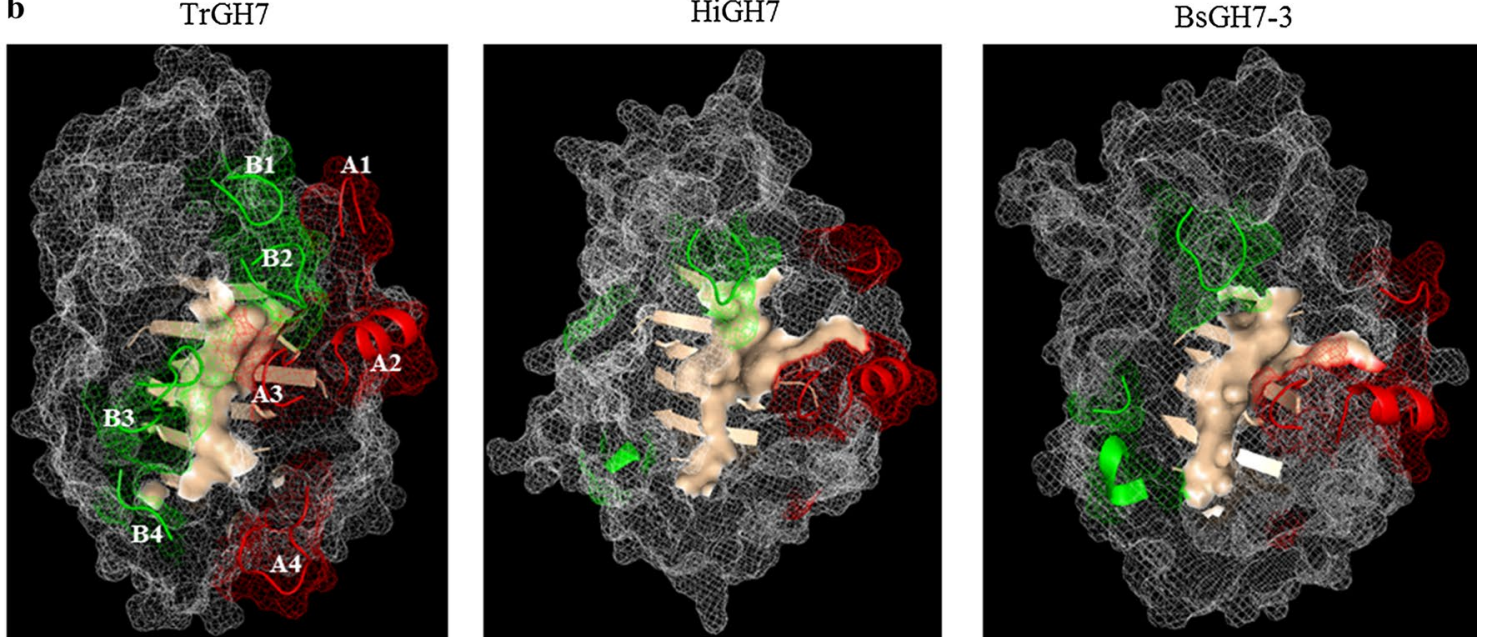

Fig. 5 Comparative analysis of B. sorokiniana GH7-3 with H. insolens endoglucanase GH7 (PDB ID: 1OJJ-B) and T. reesei cellobiohydrolase GH7 (PDB ID: 7CEL). (a) Multiple sequence alignment of BsGH7-3, HiGH7 and TrGH7. The black rectangular box contains a stretch of six residues of the catalytic motif that are conserved across the three proteins. The catalytic residues are marked with red arrows. The coloured rectangular boxes denote the residues of motifs $B$ (green), $A$ (red) and tunnel $T$ (light yellow). $\mathbf{b}$ Homology model-based structure of BsGH7-3 shows variation in the secondary structure of motifs $A, B$ and $T$ (same colour as in $\mathbf{a}$, with HiGH7 and TrGH7). The motifs $A$ (red colour) and $B$ (green colour) are in cartoon view on the mesh background. The surface view of the inner lining of the tunnel is shown in salmon colour

\section{Discussion}

Plant cell wall polysaccharides are an important source of organic compounds for use as raw material in many industrial processes and serve as a carbon source for different microorganisms including plant pathogens. Pathogens are equipped with a variety of enzymes for 
degrading polysaccharides. Although genes for many polysaccharide-degrading enzymes have been cloned over the past decade and commercial cocktails manufactured, the cost and efficiency of cellulases remain a challenge. Plant pathogens have evolved to break through the plant cell wall to utilize the plant's lignocellulose to survive. The wheat pathogen $B$. sorokiniana might thus offer unique cell wall-degrading enzymes towards a more efficient saccharification of wheat straw.

We confirmed and annotated the homologs across five GH families, GH3, GH6, GH7, GH45 and AA9, in $B$. sorokiniana genome. This genome contains different numbers of paralogs ranging from 3 (in GH6 and GH45) to 24 (in GH61) (Fig. 1; Additional file 1: Figure S2, Table S1). Paralogs of the five families show different degrees of identity suggesting that each $\mathrm{GH}$ family may have evolved and expanded at a different rate (from 6.014 to 9.155 amino acid substitutions per site) indicating functional variability (Fig. 1c). The study on transcript abundance also suggests variations in the expression of genes within each family and among the families that show up to fourfold differences in expression (Fig. 2). To get further insight into the biochemical mechanism, we selected the BsGH7-3 homolog for further characterization.

GH7 family members are amongst the most important cellulolytic enzymes that are commonly employed in plant cell wall degradation across different eukaryotic kingdoms and play a significant role in biomass hydrolysis. GH7 enzymes typically cleave $\beta-1,4$ glycosidic bonds in cellulose $/ \beta-1,4$-glucans. Endo-1,4- $\beta$-glucanase, cellobiohydrolase and endo-1,3-1,4- $\beta$-glucanase have been identified in the GH7 family. To elucidate BsGH7-3 function, we characterized the substrate specificity and modelled the structure of BsGH7-3. BsGH7-3 shows higher specific activity towards lichenan (14172.7 $\mathrm{U} \mathrm{mg}^{-1}$ ) and $\beta$-D-glucan (6739.4 $\mathrm{U} \mathrm{mg}^{-1}$ ) and the lowest activity towards Avicel (Avicel being a substrate specific to cellobiohydrolases) following the trends reported for other endoglucanases $[45,49,55]$. The $25 \%$ reduction in activity observed on the substrate PASC has also been reported for other GH7 endoglucanases [45]. This non-specific substrate specificity is a characteristic feature of the GH7 endoglucanase. BsGH7-3 effectively decreases substrate viscosity similar to the Cel7A endoglucanase from $\mathrm{Neo}$ sartorya fischeri $\mathrm{P} 1$, though this decrease is lower than that of Egl7A EG from Talaromyces emersonii CBS394.64 $[45,55]$. This reduction in substrate viscosity is also common across endoglucanases. Therefore, we have classified BsGH7-3 as an endoglucanase. The homology-based model of BsGH7-3 further suggests the enzyme to be an endoglucanase. Similar to other endoglucanase (such as HiGH7), it lacks the structural motifs A4, B2 and B3 (Fig. 5). Additionally, BsGH7-3 shows variations in the inner surface area of the binding cavity compared to HiGH7. The inner tunnel area is predicted to be $56.1 \AA^{2}$ smaller along with a smaller binding cavity on its surface than in HiGH7 [56]. This suggests possible differences in catalytic mechanism compared to HiGH7.

BsGH7-3, with a $\mathrm{pH}_{\text {opt }}$ of 8.1, is an alkaliphilic GH7. The endoglucanase from Bacillus sp. MTCC 10048 with a half-life of around $12 \mathrm{~h}$ was previously reported to be an alkaliphile [57]. Most other fungal GH7 endoglucanases reported thus far have $\mathrm{pH}$ optima between 3.5 and 7.5 [58-60]. The EG1 from Humicola grisea var. thermoidea has been reported to show an optimal $\mathrm{pH} 5.0$ though the enzyme was reported to be stable between $\mathrm{pH}$ 5.0 and 11.0 at $4{ }^{\circ} \mathrm{C}$ for $20 \mathrm{~h}$ [60]. The alkaliphilic nature also makes BsGH7-3 compatible to AFEX or lime pretreatment of biomass [61]. With a $65 \%$ residual activity after more than 15 days $(365 \mathrm{~h})$ at $T_{\mathrm{opt}}$, the half-life of BsGH7-3 is amongst the highest reported compared to other $\mathrm{GH} 7$ endoglucanases, particularly at high $\mathrm{pH}$ [58]. Chokhawala et al. reported the expression of an engineered T. reesei EGI variant in T. reesei (G230A/D113S/ D115T Tr_TrEG1) with a half-life of $161 \mathrm{~h}$ at $60{ }^{\circ} \mathrm{C}$ and $\mathrm{pH} 4.85$ in comparison to the recombinant (T. reesei host) wild-type TrEG1 with a half-life of $74 \mathrm{~h}$ at $60^{\circ} \mathrm{C}, \mathrm{pH}$ 4.85 [62]. Another EG from Trichoderma harzianum has also been reported to be very stable, with a little change in activity after 2 months of incubation (Additional file 1: Table S3). Here too, the enzyme has a very low turnover number at $0.45 \mathrm{~s}^{-1}$ on the substrate xyloglucan [63]. The alkaliphilic endoglucanase from the Bacillus sp. MTCC 10048 also shows little activity with a turnover number of $0.55 \mathrm{~s}^{-1}$ [57]. Therefore, the comparatively high kinetic efficiency with a $k_{\text {cat }}$ of $4.8 \mathrm{~s}^{-1}$ and high stability makes BsGH7-3 a very promising alkaliphilic endoglucanase.

The stimulatory effect of BsGH7-3 observed in the presence of divalent metal ions, $\mathrm{Mn}^{2+}$ and $\mathrm{Fe}^{2+}$, is intriguing. Metal binding studies indicate that the enzyme is not a metalloenzyme since the 3 - to 5 -fold increase observed in the presence of metals is reversed upon metal removal. While the stimulation by metal ions has been previously reported across cellulases, and in particular stimulation of endoglucanase activity, no mechanisms have been proposed [64-68]. The activity increase is probably due to better folding of the protein and possible metal-induced multimerization effects that enhance protein stability. Further experiments are required to understand the role of metal ions in the stability of this enzyme. The enzyme was also stable in the presence of four commercial detergents tested, with residual activity in the range of $51-74 \%$. Although ILs are also known to denature enzymes, there are some reports of endoglucanases which are stable towards ILs. The endoglucanases from Stachybotrys microspora are $50 \%$ active in the presence 
of 20\% (v/v) 1-butyl-3-methylimidazolium chloride [59]. Gladden et al. reported an endoglucanase from GH12 with the highest activity in the presence of $15 \%(\mathrm{v} / \mathrm{v})$

1-ethyl-3-methylimidazolium acetate ([C2mim] [OAc]) and another from GH5 with the highest activity in 25\% [C2mim][OAc] [69]. BsGH7-3 does not show any loss in activity in the presence of $20 \%(\mathrm{v} / \mathrm{v})$ of the three ILs tested, indicating high stability and compatibility to IL pretreatment.

BsGH7-3 tolerates salt and also shows up to 1.25-fold increase in activity in the presence of salt. Sequence analysis shows that the acidic residues account for $12 \%$ of the total residues and the $\mathrm{pI}$ of the protein as determined by ProtParam is 4.96 [70]. Acidic amino acid residues help create a salt hydration shell to resist the denaturing environment created by high salt concentration and confer stability to the protein [71-73].

\section{Conclusions}

Here we report the annotation and characterization of cellulase genes in B. sorokiniana and derive phylogenetic inferences. Based on expression profiling of the cellulase genes, the third homolog of GH7 was characterized to be an endoglucanase from the GH7 family. The enzyme is highly thermostable, salt tolerant and of higher kinetic competence than most similarly thermostable fungal GH7 EGs. Several other cellulase genes of the pathogen have also been shortlisted based on expression levels, and their characterization is ongoing in the laboratory. We hope that this methodology of searching and screening will further enhance the repertoire of promising enzymes, particularly in plant pathogens, and help us find novel enzymes in the degradation of specific plant biomass.

\section{Additional file}

Additional file 1. Supplemental material to "Genome-wide characterization of cellulases from the hemi-biotrophic plant pathogen, Bipolaris sorokiniana, reveals presence of a highly stable GH7 endoglucanase". Figure S1. Transcript sequences of B. sorokiniana $\mathrm{GHs}(\mathrm{GH} 3, \mathrm{GH} 6, \mathrm{GH} 7$ and $G H 45)$ and $A A 9$ genes. Figure S2. Genomic architecture of $B$. sorokiniana $\mathrm{GHs}$ and redox enzymes (AA9). The figure shows the schematic of arrangement of introns and exons in each of the BsGH homologs (comparative lengths are unscaled). Figure $\mathbf{S 3}$. Multiple sequence alignment of protein sequences of B. sorokiniana $\mathrm{GH}$ s and AA9. Figure S4. Complete CDS sequence of $B$. sorokiniana $\mathrm{GH} 7-3$ as obtained after sequencing. Figure S5. (a) The upper and lower diagonal in matrix represents the \% of identities between the sequences and RMSD $(\AA)$ between the structures of TrGH7 (7CEL-A), HiGH7 (1OJJ-B) and BsGH7-3 respectively. (b) The structural diversities in the binding. regions among $\mathrm{TrGH} 7, \mathrm{HiGH7}$ and $\mathrm{BsGH7}-3$. (c) Comparative electrostatic potential distribution between $\mathrm{TrGH} 7, \mathrm{HiGH} 7$ and BsGH7-3. Table S1. The genomic features of B. sorokiniana GHs and AA9 genes. Details of length of exons and ORF coordinates of B. sorokiniana GHs and $A A 9$ transcripts. Table S2. (a) Details of primers used for qPCR analysis of B. sorokiniana GHs transcripts (b) Details of primers used for cloning of BsGH7-3 transcripts. Table S3. Comparison of BsGH7-3 with other fungal endoglucanases of the $\mathrm{GH} 7$ family with $\mathrm{CMC}$ as the substrate.

\section{Abbreviations}

EG: endoglucanase; $\mathrm{CBH}$ : cellobiohydrolase; CMC: carboxymethyl cellulose; Bs: Bipolaris sorokiniana; $\left[\mathrm{C}_{2}\right.$ mim]: 1-ethyl-3-methylimidazolium; $\left[\mathrm{C}_{2} \mathrm{C}_{1} \mathrm{im}\right][\mathrm{Cl}]$ : 1-ethyl-3-methylimidazolium chloride; $\left[\mathrm{C}_{2} \mathrm{C}_{1}\right.$ im] $\left[\mathrm{MeCO}_{2}\right]$ : 1-ethyl-3-methylimidazolium acetate; $\left[\mathrm{C}_{2} \mathrm{C}_{1} i m\right]\left[\mathrm{C}_{2} \mathrm{C}_{2} \mathrm{PO}_{4}\right]$ : 1-ethyl-3-methylimidazolium phosphate; AA: auxiliary activity; GH: glycoside hydrolase family 7 ; IL: ionic liquid; PASC: phosphoric acid swollen cellulose; ICP-MS: inductively coupled plasma mass spectrometry; $t_{1 / 2}$ : half-life.

\section{Authors' contributions}

SA and RKS contributed equally to this work. SD and SPP designed the study; SA, RKS and PK conducted the study and analysed the data; SD and SPP participated in conducting the study and data analysis as well as provided resources. All the authors participated in writing the manuscript. All authors read and approved the final manuscript.

\section{Author details}

${ }^{1}$ Department of Biological Sciences, Indian Institute of Science Education and Research Kolkata, Mohanpur 741246, India. ${ }^{2}$ Protein Engineering Laboratory, Department of Biological Sciences, Indian Institute of Science Education and Research Kolkata, Mohanpur, India. ${ }^{3}$ Centre for Advanced Functional Materials, Indian Institute of Science Education and Research Kolkata, Mohanpur, India.

\section{Acknowledgements}

SD and SPP gratefully acknowledge the additional support by Indian Institute of Science Education and Research Kolkata. SA and PK acknowledge the support by IISER Kolkata Institute fellowship.

\section{Competing interests}

The authors declare that they have no competing interests.

\section{Availability of supporting data}

Additional file 1: Supplemental material to "Genome-wide characterization of cellulases from the hemi-biotrophic plant pathogen, Bipolaris sorokiniana, reveals presence of a highly stable GH7 endoglucanase".

\section{Consent for publication}

All authors approved the manuscript and this submission.

\section{Funding}

This work was supported in part by Rapid Grant for Young Investigators, Department of Biotechnology, Government of India, BT/PR6511/ GBD/27/424/2012 (SD), Energy Bioscience Overseas Fellowship, Department of Biotechnology, Government of India, BT/NBDB/22/06/2011 (SD), Science \& Engineering Research Board, EMR/2016/003705 (SD) and by the WHEAT Competitive Grants Initiative, CIMMYT and the CGIAR, A4031.09.10 (SPP). RKS is supported by the MPG-India partner group program of the Max Planck Society, Germany and the Indo-German Centre for Science and Technology/ Department of Science and Technology, Government of India (SPP).

\section{Publisher's Note}

Springer Nature remains neutral with regard to jurisdictional claims in published maps and institutional affiliations.

Received: 25 January 2017 Accepted: 17 May 2017

Published online: 25 May 2017

\section{References}

1. Durand H, Clanet M, Tiraby G. Genetic improvement of Trichoderma reesei for large scale cellulase production. Enzyme Microbiol Technol. 1988;10(6):341-6.

2. Martinez D, Berka RM, Henrissat B, Saloheimo M, Arvas M, Baker SE, Chapman J, Chertkov O, Coutinho PM, Cullen D, et al. Genome sequencing and analysis of the biomass-degrading fungus Trichoderma reesei (syn. Hypocrea jecorina). Nat Biotechnol. 2008;26(5):553-60. 
3. Harris PV, Welner D, McFarland KC, Re E, Navarro Poulsen JC, Brown K, Salbo R, Ding H, Vlasenko E, Merino S, et al. Stimulation of lignocellulosic biomass hydrolysis by proteins of glycoside hydrolase family 61: structure and function of a large, enigmatic family. Biochemistry. 2010;49(15):3305-16.

4. Datta S. Recent strategies to overexpress and engineer cellulases for biomass degradation. Curr Metabol. 2016;4(1):14-22.

5. Walton JD. Deconstructing the cell wall. Plant Physiol. 1994;104(4):1113-8.

6. Skamnioti P, Furlong RF, Gurr SJ. The fate of gene duplicates in the genomes of fungal pathogens. Commun Integr Biol. 2008;1(2):196-8.

7. Zhao Z, Liu H, Wang C, Xu J-R. Erratum to: comparative analysis of fungal genomes reveals different plant cell wall degrading capacity in fungi. BMC Genom. 2014;15:6.

8. Couturier M, Navarro D, Olivé C, Chevret D, Haon M, Favel A, LesageMeessen L, Henrissat B, Coutinho PM, Berrin J-G. Post-genomic analyses of fungal lignocellulosic biomass degradation reveal the unexpected potential of the plant pathogen Ustilago maydis. BMC Genom. 2012;13:57.

9. King BC, Waxman KD, Nenni NV, Walker LP, Bergstrom GC, Gibson DM. Arsenal of plant cell wall degrading enzymes reflects host preference among plant pathogenic fungi. Biotechnol Biofuels. 2011;4:4.

10. Woodward J, Wiseman A. Fungal and other $\beta$-glucosidases - their properties and applications. Enzyme Microbial Technol. 1982;4(2):73-9.

11. Väljamäe P, Sild V, Nutt A, Pettersson G, Johansson G. Acid hydrolysis of bacterial cellulose reveals different modes of synergistic action between cellobiohydrolase I and endoglucanase I. Eur J Biochem. 1999;266(2):327-34.

12. Zhang YH, Lynd LR. A functionally based model for hydrolysis of cellulose by fungal cellulase. Biotechnol Bioeng. 2006;94(5):888-98.

13. Sahu R, Sharaff M, Pradhan M, Sethi A, Bandyopadhyay T, Mishra VK, Chand R, Chowdhury AK, Joshi AK, Pandey SP. Elucidation of defenserelated signaling responses to spot blotch infection in bread wheat (Triticum aestivum L.). Plant J. 2016;86(1):35-49.

14. Chand R, Pandey S, Singh H, Kumar S, Joshi A. Variability and its probable cause in natural populations of spot blotch pathogen Bipolaris sorokiniana of wheat (T. aestivum L.) in India. J Plant Dis Prot. 2003;110(1):27-35

15. Pandey S, Sharma S, Chand R, Shahi P, Joshi AK. Clonal variability and Its relevance in generation of new pathotypes in the spot blotch pathogen, Bipolaris sorokiniana. Curr Microbiol. 2008;56:33-41.

16. Bouton JH. Molecular breeding of switchgrass for use as a biofuel crop. Curr Opin Genet Dev. 2007;17(6):553-8.

17. Geimba MP, Riffel A, Agostini V, Brandelli A. Characterisation of cellulosehydrolysing enzymes from the fungus Bipolaris sorokiniana. J Sci Food Agric. 1999;79(13):1849-54.

18. Geimba MP, Brandelli A. Extracellular enzymatic activities of Bipolaris sorokiniana isolates. J Basic Microbiol. 2002;42(4):246-53.

19. Ohm RA, Feau N, Henrissat B, Schoch CL, Horwitz BA, Barry KW, Condon BJ, Copeland AC, Dhillon B, Glaser F, et al. Diverse lifestyles and strategies of plant pathogenesis encoded in the genomes of eighteen Dothideomycetes fungi. PLoS Pathog. 2012;8(12):e1003037.

20. Condon BJ, Leng Y, Wu D, Bushley KE, Ohm RA, Otillar R, Martin J, Schackwitz W, Grimwood J, MohdZainudin N, et al. Comparative genome structure, secondary metabolite, and effector coding capacity across Cochliobolus pathogens. PLoS Genet. 2013;9(1):e1003233.

21. Cantarel BL, Coutinho PM, Rancurel C, Bernard T, Lombard V, Henrissat B. The carbohydrate-active enzymes database (CAZy): an expert resource for glycogenomics. Nucleic Acids Res. 2009;37(Database issue):D233-8.

22. Huang Y, Niu B, Gao Y, Fu L, Li W. CD-HIT Suite: a web server for clustering and comparing biological sequences. Bioinformatics. 2010;26(5):680-2.

23. Katoh K, Misawa K, Kuma K, Miyata T. MAFFT: a novel method for rapid multiple sequence alignment based on fast Fourier transform. Nucleic Acids Res. 2002;30(14):3059-66.

24. Finn RD, Coggill P, Eberhardt RY, Eddy SR, Mistry J, Mitchell AL, Potte SC, Punta M, Qureshi M, Sangrador-Vegas A, et al. The Pfam protein families database: towards a more sustainable future. Nucleic Acids Res. 2016;44(D1):D279-85.

25. Jones L, Keining T, Eamens A, Vaistij FE. Virus-induced gene silencing of Argonaute genes in Nicotiana benthamiana demonstrates that extensive systemic silencing requires Argonaute 1-like and Argonaute 4-like genes. Plant Physiol. 2006;141(2):598-606.
26. Mohanta TK, Arora PK, Mohanta N, Parida P, Bae H. Identification of new members of the MAPK gene family in plants shows diverse conserved domains and novel activation loop variants. BMC Genom. 2015;16(1):58.

27. Gabaldon T, Koonin EV. Functional and evolutionary implications of gene orthology. Nat Rev Genet. 2013;14(5):360-6.

28. Singh RK, Gase K, Baldwin IT, Pandey SP. Molecular evolution and diversification of the Argonaute family of proteins in plants. BMC Plant Biol. 2015;15(1):23.

29. Stamatakis A. RAxML version 8: a tool for phylogenetic analysis and postanalysis of large phylogenies. Bioinformatics. 2014;30(9):1312-3.

30. Maddison WP, Donoghue MJ, Maddison DR. Outgroup analysis and parsimony. Syst Biol. 1984;33(1):83-103.

31. Pearson T, Hornstra HM, Sahl JW, Schaack S, Schupp JM, Beckstrom-Sternberg SM, O'Neill MW, Priestley RA, Champion MD, Beckstrom-Sternberg JS, et al. When outgroups fail; phylogenomics of rooting the emerging pathogen, Coxiella burnetii. Syst Biol. 2013;62(5):752-62.

32. Tamura K, Peterson D, Peterson N, Stecher G, Nei M, Kumar S. MEGA5: molecular evolutionary genetics analysis using maximum likelihood, evolutionary distance, and maximum parsimony methods. Mol Biol Evol. 2011:28(10):2731-9.

33. Hu B, Jin J, Guo A-Y, Zhang H, Luo J, Gao G. GSDS 2.0: an upgraded gene feature visualization server. Bioinformatics. 2015;31(8):1296-7.

34. Sievers F, Wilm A, Dineen D, Gibson TJ, Karplus K, Li W, Lopez R, McWilliam $\mathrm{H}$, Remmert M, Soding J, et al. Fast, scalable generation of high-quality protein multiple sequence alignments using Clustal Omega. Mol Syst Biol. 2011;7:539.

35. Söding J, Biegert A, Lupas AN. The HHpred interactive server for protein homology detection and structure prediction. Nucleic Acids Res. 2005;33(Web Server issue):W244-8.

36. Zhang Y, Skolnick J. TM-align: a protein structure alignment algorithm based on the TM-score. Nucleic Acids Res. 2005;33(7):2302-9.

37. Dundas J, Ouyang Z, Tseng J, Binkowski A, Turpaz Y, Liang J. CASTp: computed atlas of surface topography of proteins with structural and topographical mapping of functionally annotated residues. Nucleic Acids Res. 2006;34(Web Server issue):W116-8.

38. Shazman S, Celniker G, Haber O, Glaser F, Mandel-Gutfreund Y. Patch Finder Plus (PFplus): a web server for extracting and displaying positive electrostatic patches on protein surfaces. Nucleic Acids Res. 2007;35(Web Server issue):W526-30.

39. Schrodinger, LLC: the PyMOL Molecular Graphics System, Version 1.8 (www.pymol.org). In; 2015.

40. Liljeroth $\mathrm{E}$, Jansson HB, Schafer W. Transformation of Bipolaris-sorokiniana with the Gus gene and use for studying fungal colonization of barley roots. Phytopathology. 1993;83:1484-9.

41. Jaiswal SK, Prasad LC, Sharma S, Kumar S, Prasad R, Pandey SP, Chand R, Joshi AK. Identification of molecular marker and aggressiveness for different groups of Bipolaris sorokiniana isolates causing spot blotch disease in wheat (Triticum aestivum L.). Curr Microbiol. 2007;55(2):135-41.

42. Bradford MM. A rapid and sensitive method for the quantitation of microgram quantities of protein utilizing the principle of protein-dye binding. Anal Biochem. 1976;72:248-54.

43. Miller GL. Use of dinitrosalicylic acid reagent for determination of reducing sugar. Anal Chem. 1959;31(3):426-8.

44. Walseth CS. Occurrence of cellulases in enzyme preparations from microorganisms. Tappi. 1952:35(5):228-33.

45. Liu Y, Dun B, Shi P, Ma R, Luo H, Bai Y, Xie X, Yao B. A novel GH7 Endo- $\beta-1,4-$ Glucanase from Neosartorya fischeri P1 with good thermostability, broad substrate specificity and potential application in the brewing industry. PLOS ONE. 2015:10(9):e0137485.

46. Himmel ME, Ding SY, Johnson DK, Adney WS, Nimlos MR, Brady JW. Biomass recalcitrance: engineering plants and enzymes for biofuels production. Science. 2007:315(5813):804-7.

47. Garcia-Vallve S, Romeu A, Palau J. Horizontal gene transfer of glycosyl hydrolases of the rumen fungi. Mol Biol Evol. 2000;17(3):352-61.

48. Lucas R, Robles A, Garcia MT, Alvarez De Cienfuegos G, Galvez A. Production, purification, and properties of an endoglucanase produced by the hyphomycete Chalara (Syn. Thielaviopsis) paradoxa CH32. J Agric Food Chem. 2001:49(1):79-85.

49. Zhang L, Fan Y, Zheng H, Du F, Zhang KQ, Huang X, Wang L, Zhang M, Niu $\mathrm{Q}$. Isolation and characterization of a novel endoglucanase from a Bursaphelenchus xylophilus metagenomic library. PLoS ONE. 2013;8(12):e82437. 
50. Sheldon RA, Lau RM, Sorgedrager MJ, van Rantwijk F, Seddon KR. Biocatalysis in ionic liquids. Green Chem. 2002;4(2):147-51.

51. Sinha SK, Datta S. $\beta$-Glucosidase from the hyperthermophilic archaeon Thermococcus sp. is a salt-tolerant enzyme that is stabilized by its reaction product glucose. Appl Microbiol Biotechnol. 2016;100(19):8399-409.

52. Goswami S, Gupta N, Datta S. Using the $\beta$-glucosidase catalyzed reaction product glucose to improve the ionic liquid tolerance of $\beta$-glucosidases. Biotechnol Biofuels. 2016;9:72.

53. Ubhayasekera W, Munoz IG, Vasella A, Stahlberg J, Mowbray SL. Structures of Phanerochaete chrysosporium Cel7D in complex with product and inhibitors. FEBS J. 2005:272(8):1952-64.

54. Knott BC, Crowley MF, Himmel ME, Ståhlberg J, Beckham GT. Carbohydrate-protein interactions that drive processive polysaccharide translocation in enzymes revealed from a computational study of cellobiohydrolase processivity. J Am Chem Soc. 2014;136(24):8810-9.

55. Wang K, Luo H, Shi P, Huang H, Bai Y, Yao B. A highly-active endo-1,31,4- $\beta$-glucanase from thermophilic Talaromyces emersonii CBS394.64 with application potential in the brewing and feed industries. Process Biochem. 2014;49(9):1448-56.

56. Ducros VM, Tarling CA, Zechel DL, Brzozowski AM, Frandsen TP, von Ossowski I, Schulein M, Withers SG, Davies GJ. Anatomy of glycosynthesis: structure and kinetics of the Humicola insolens Cel7B E197A and E197S glycosynthase mutants. Chem Biol. 2003;10(7):619-28.

57. Sadhu S, Saha P, Sen SK, Mayilraj S, Maiti TK. Production, purification and characterization of a novel thermotolerant endoglucanase (CMCase) from Bacillus strain isolated from cow dung. SpringerPlus. 2013;2(1):10.

58. Payne CM, Knott BC, Mayes HB, Hansson H, Himmel ME, Sandgren M, Stahlberg J, Beckham GT. Fungal cellulases. Chem Rev. 2015;115(3):1308-448

59. Ben Hmad I, Boudabbous M, Belghith H, Gargouri A. A novel ionic liquidstable halophilic endoglucanase from Stachybotrys microspora. Process Biochem. 2017;54:59-66.

60. Takashima S, Nakamura A, Hidaka M, Masaki H, Uozumi T. Cloning, sequencing, and expression of the cellulase genes of Humicola grisea var. thermoidea. J Biotechnol. 1996;50(2):137-47.

61. da Costa Sousa L, Chundawat SP, Balan V, Dale BE. 'Cradle-to-grave' assessment of existing lignocellulose pretreatment technologies. Curr Opin Biotechnol. 2009;20(3):339-47.

62. Chokhawala HA, Roche CM, Kim T-W, Atreya ME, Vegesna N, Dana CM, Blanch HW, Clark DS. Mutagenesis of Trichoderma reesei endoglucanase I: impact of expression host on activity and stability at elevated temperatures. BMC Biotechnol. 2015;15(1):1-12.
63. Pellegrini VO, Serpa VI, Godoy AS, Camilo CM, Bernardes A, Rezende CA, Junior NP, Franco Cairo JP, Squina FM, Polikarpov I. Recombinant Trichoderma harzianum endoglucanase I (Cel7B) is a highly acidic and promiscuous carbohydrate-active enzyme. Appl Microbiol Biotechnol. 2015;99(22):9591-604.

64. Kern M, McGeehan JE, Streeter SD, Martin RN, Besser K, Elias L, Eborall W, Malyon GP, Payne CM, Himmel ME, et al. Structural characterization of a unique marine animal family 7 cellobiohydrolase suggests a mechanism of cellulase salt tolerance. Proc Natl Acad Sci USA. 2013;110(25):10189-94.

65. You S, Tu T, Zhang L, Wang Y, Huang H, Ma R, Shi P, Bai Y, Su X, Lin Z, et al. Improvement of the thermostability and catalytic efficiency of a highly active $\beta$-glucanase from Talaromyces leycettanus JCM12802 by optimizing residual charge-charge interactions. Biotechnol Biofuels. 2016;9(1):1-12.

66. Theberge M, Lacaze P, Shareck F, Morosoli R, Kluepfel D. Purification and characterization of an endoglucanase from Streptomyces lividans 66 and DNA sequence of the gene. Appl Environ Microbiol. 1992;58(3):815-20.

67. Rawat R, Kumar S, Chadha BS, Kumar D, Oberoi HS. An acidothermophilic functionally active novel GH12 family endoglucanase from Aspergillus niger $\mathrm{HO}$ : purification, characterization and molecular interaction studies. Antonie Van Leeuwenhoek. 2015;107(1):103-17.

68. Li CH, Wang HR, Yan TR. Cloning, purification, and characterization of a heat- and alkaline-stable endoglucanase B from Aspergillus niger BCRC31494. Molecules. 2012;17(8):9774-89.

69. Gladden JM, Park JI, Bergmann J, Reyes-Ortiz V, D'Haeseleer P, Quirino BF, Sale KL, Simmons BA, Singer SW. Discovery and characterization of ionic liquid-tolerant thermophilic cellulases from a switchgrass-adapted microbial community. Biotechnol Biofuels. 2014;7:15.

70. Gasteiger E, Hoogland C, Gattiker A, Duvaud SE, Wilkins MR, Appel RD, Bairoch A. Protein identification and analysis tools on the ExPASy server. In: Walker JM, editor. The proteomics protocols handbook. Totowa: Humana Press; 2005. p. 571-607.

71. Hirasawa K, Uchimura K, Kashiwa M, Grant WD, Ito S, Kobayashi T, Horikoshi K. Salt-activated endoglucanase of a strain of alkaliphilic Bacillus agaradhaerens. Antonie Van Leeuwenhoek. 2006;89(2):211-9.

72. Zhang T, Datta S, Eichler J, Ivanova N, Axen SD, Kerfeld CA, Chen F, Kyrpides N, Hugenholtz P, Cheng J-F, et al. Identification of a haloalkaliphilic and thermostable cellulase with improved ionic liquid tolerance. Green Chem. 2011;13(8):2083-90

73. Endo K, Hakamada Y, Takizawa S, Kubota H, Sumitomo N, Kobayashi T, Ito S. A novel alkaline endoglucanase from an alkaliphilic Bacillus isolate: enzymatic properties, and nucleotide and deduced amino acid sequences. Appl Microbiol Biotechnol. 2001;57(1):109-16.

\section{Submit your next manuscript to BioMed Central and we will help you at every step:}

- We accept pre-submission inquiries

- Our selector tool helps you to find the most relevant journal

- We provide round the clock customer support

- Convenient online submission

- Thorough peer review

- Inclusion in PubMed and all major indexing services

- Maximum visibility for your research

Submit your manuscript at www.biomedcentral.com/submit
(OioMed Central 